\title{
Linkage of cave-ice changes to weather patterns inside and outside the cave Eisriesenwelt (Tennengebirge, Austria)
}

\author{
W. Schöner ${ }^{1}$, G. Weyss ${ }^{1}$, and E. Mursch-Radlgruber ${ }^{2}$ \\ ${ }^{1}$ Central Institute for Meteorology and Geodynamics, Vienna, Austria \\ ${ }^{2}$ University of Natural Resources and Applied Life Sciences BOKU, Vienna, Austria
}

Received: 20 August 2010 - Published in The Cryosphere Discuss.: 17 September 2010

Revised: 29 June 2011 - Accepted: 6 July 2011 - Published: 11 August 2011

\begin{abstract}
The behaviour of perennial ice masses in karst caves in relation to the outside climate is still not well understood, though a significant potential of the cave-ice for paleo-climate reconstructions could be expected. This study investigates the relationship between weather patterns inside and outside the cave Eisriesenwelt (Austrian Alps) and icesurface changes of the ice-covered part of the cave from meteorological observations at three sites (outside the cave, entrance-near inside and in the middle section of the cave) including atmospheric and ice surface measurements as well as an ablation stake network. Whereas ice loss in summer was a general feature from stake measurements for almost all measurement sites in the cave in 2007, 2008 and 2009 (values up to $-15 \mathrm{~cm} \mathrm{yr}^{-1}$ ), a clear seasonal signal of ice accumulation (e.g. in spring as expected from theory) was not observed. It is shown that under recent climate the cave ice mass balance is more sensitive to winter climate for the inner measurement site and sensitive to winter and summer climate for the entrance-near site. Observed ice surface changes can be well explained by cave atmosphere measurements, indicating a clear annual cycle with weak mass loss in winter due to sublimation, stable ice conditions in spring until summer (autumn for the inner measurement site) and significant melt in late summer to autumn (for the entrance-near site). Interestingly, surface ice melt did not contribute to ablation at the inner site. It is obvious from the spatial sample of ice surface height observations that the ice body is currently in rather balanced state, though the influence of show-cave management on ice mass-balance could not be clearly quantified (but a significant input on accumulation for some parts of the cave is rather plausible).
\end{abstract}

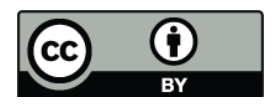

Correspondence to: W. Schöner (wolfgang.schoener@zamg.ac.at)

\section{Introduction}

Ice fillings are eye-catching features in several karst caves worldwide. The ice is formed mainly from refreezing of percolation water and, with much less contribution, from deposition of cave-air water vapour. If ice formation generally exceeds loss due to ice melt and ice evaporation (sublimation) a layered ice body will be formed. Today ice-caves are frequently used as show-caves for tourism because of their impressive appearance. However, ice caves could also provide - because of the layered structure of the ice - the potential of high-resolution climate proxy information (Silvestru, 1999; Homlund et al., 2005; May et al., 2011). The values and the processes of both cave ice accumulation and ablation, however, are still not well understood and vary between individual caves. In general static and dynamic ice-caves are to be distinguished (Luetscher and Jeannin, 2004), where the classification refers to the relationship between ice-formation and air circulation in the cave. Whereas static ice caves feature a much simpler air circulation system and related cave climate (driven from the influence of air temperature on air-density, similar to cold-air pools in sink holes), dynamic ice-caves are characterized by an interconnected system of highly structured cave passages with at least two interacting entrances, resulting in a complicated air flow system. Details on the relationship between ice cave type and cave air dynamics are to be found in e.g. Luetscher and Jeannin (2004). In comparison to karst-caves without ice filling ice caves have additional significant influence on air flow dynamics from the hygro-thermal conditions of the ice body.

Pioneer work on air ventilation in an ice cave were done by Saar $(1956,1957)$, who already found clear relationships between meteorological conditions inside and outside the cave Rieseneishöhle (Dachstein, Austria). Extensive studies covering the investigation of surface energy fluxes in ice caves are, however, quite new (Ohata et al., 1994a,b;

Published by Copernicus Publications on behalf of the European Geosciences Union. 
Luetscher et al., 2008). Detailed studies on cave climate and ice mass balance in ice caves are available for the static icecaves Scarisoara in Romania (Silvestru, 1999; Racovita and Onac, 2000; Persoiu et al., 2007) and Dobsinska in Slovakia (e.g. Pflitsch et al., 2007; Vrana et al., 2007). First highquality dating of basal ice from Scarisoara yielded ages of $\approx 10000 \mathrm{BP}$ (Persoiu and Onac, 2010). Thus this ice cave most likely could offer a continuous Holocene temperature chronology from an ice core taken in 2003 (Persoiu and Onac, 2010).

Eisriesenwelt (Tennengebirge, Austrian Alps see Fig. 1) is known as one of the largest ice caves in the world with an ice covered area of about $10000 \mathrm{~m}^{2}$ and about $33000 \mathrm{~m}^{3}$ of ice volume (Silvestru, 1999). Contrary to Scarisoara and Dobsinska it is a dynamic ice cave, with a total length of the cave system of $42 \mathrm{~km}$ (Pfarr and Stummer, 1988). About $700 \mathrm{~m}$ of the entrance-near part of the cave are covered by an ice body. The cave entrance at an elevation of $1641 \mathrm{~m}$ is situated in a steep rock wall of Tennengebirge facing towards Southwest. It can be accessed by cable car and about 15 min walk. From the entrance to the remotest ice covered parts of the cave elevation increases by $158 \mathrm{~m}$ with highest section (1774 $\mathrm{m}$ a.s.l.) of the ice cave lying inbetween. First detailed scientific studies on the cave already date back to the early 1930s (e.g. Oedl, 1922; Hauser and Oedl, 1923). Since 1920 the Eisriesenwelt (denoted ERW hereafter) is used as show-cave opened from about May to October each year. During this period the main-entrance of the cave is closed (interrupted only by short events in order to leave visitors in and out). For more than 10 years now regular air temperature measurements in the cave have been done by the show-cave operator which were summarized in Thaler (2008).

Within the period 2006 to 2009 the Eisriesenwelt cave was subject of the project AUSTRO*ICE*CAVE*2100 which aimed to explore the potential of the cave ice for climate proxy information and climate reconstruction. In order to meet this aims the project included not only sampling of cave ice from coring but also the investigation of the relationship between ice body mass balance and the weather and climate patterns inside and outside the cave. With such an approach it was aimed to understand both the formation of a possible layered structure of the ice body as well as the seasonal reference of the supposed cave-ice climate proxy signal. Consequently, AUSTRO*ICE*CAVE*2100 included the sub-tasks:

- geometrical characterization of the ice body at the coring location by GPR survey (see Behm and Hausmann, 2007; Hausmann and Behm, 2011)

- coring and stable-isotope measurements of ice samples (May et al., 2011)

- mass and energy balance of ice body at the coring site (Obleitner and Spötl, 2011)

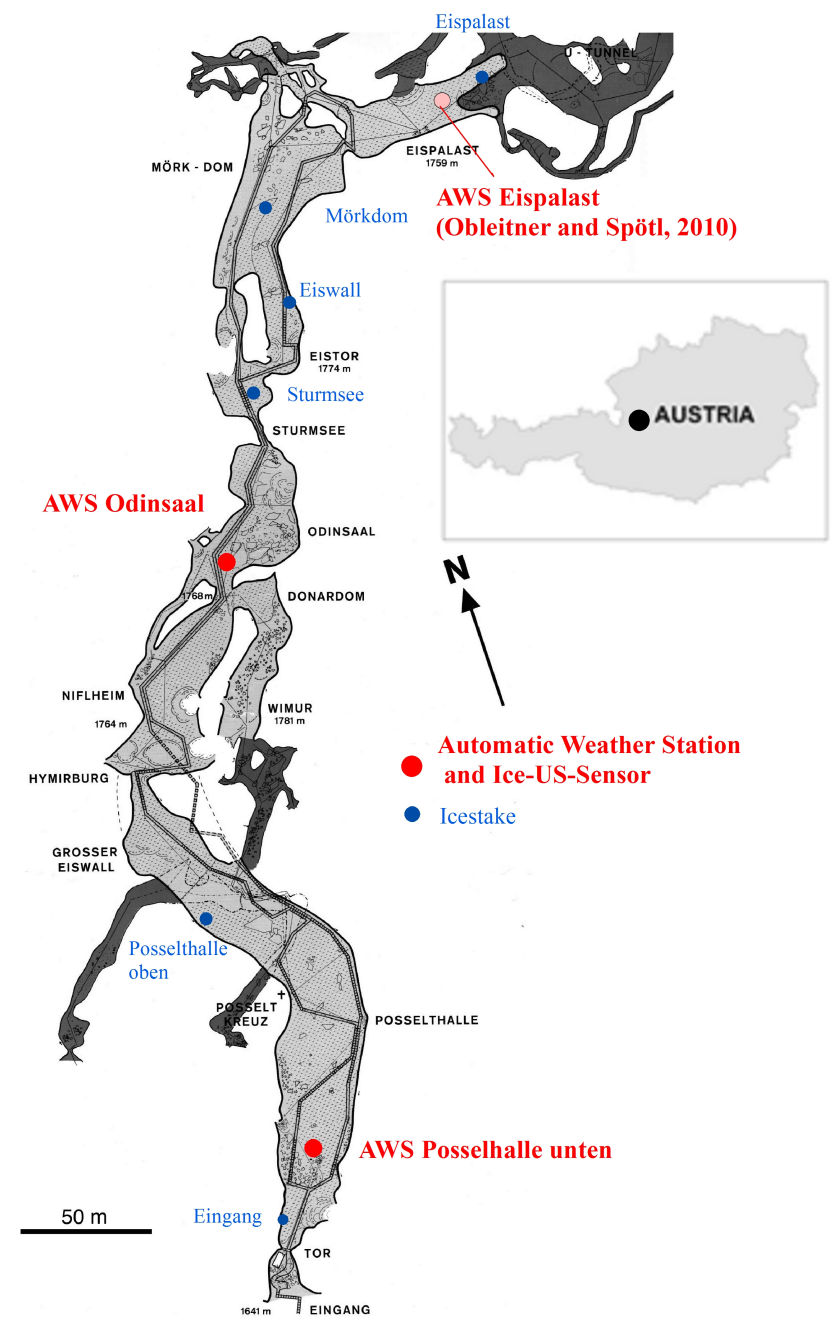

Fig. 1. Map of Eisriesenwelt and location of ice stakes (blue) and weather-stations (red) for this study. Light-grey areas marks the ice covered part of Eisriesenwelt cave, dark-grey areas marks the nonice covered part of the cave with the overlying second entrance in the lower part of the figure.

- linkage of coring site ice mass balance to other parts of the cave as well as to inside and outside cave atmosphere circulation patterns (this paper).

\section{Methodical concept and data}

In order to quantify changes of the cave ice body and their linkages to atmospheric conditions both the mass balance and the energy balance at the ice surface have to be considered. Detailed measurements of the energy fluxes in the ice as well as between the cave atmosphere and the ice surface including a modeling approach for Eisriesenwelt cave were done by Obleitner and Spötl (2011) for the site Eispalast (see Fig. 1). In our study we rely on the results of Obleitner and Spötl (2011) and introduce only a basic concept of the 
energy and mass balance at ice surface in order to enable the interpretation of our ice surface changes with respect to the underlying energy fluxes and air circulation between inside and outside the cave. For a given location e.g. the Automatic Weather Station (AWS) site the specific mass balance $b$ (mass balance per unit area) can be written as the sum of mass gain $c$ and mass loss $a$ :

$b=c+a \quad\left(\mathrm{~kg} \mathrm{~m}^{-2}\right)$

with $c$ is specific accumulation (coming from either refreezing of seepage water or deposition) and $a$ is specific ablation (either from ice melt or from ice evaporation). In fact $b$ is the result of temporal fluctuations of both $c$ and $a$ and can be obtained from changes in ice body surface height $h$ with layer density $\rho$ (which was assumed to be constant for the cave ice with $920 \mathrm{~kg} \mathrm{~m}^{-3}$ ) for a given reference period $t_{1} t_{2}$ :

$b=\int_{t_{2}}^{t_{1}} \frac{\partial c+\partial a}{\partial t}=\int_{t_{2}}^{t_{1}} \varrho \frac{\mathrm{d} h}{\mathrm{~d} t} \quad\left(\mathrm{~kg} \mathrm{~m}^{-2}\right)$.

As the ice body of Eisriesenwelt is shallow (less than $2 \mathrm{~m}$ ice-thickness at the 2 AWS sites), internal ice deformation and ice flow over bedrock could be neglected.

The specific mass balance $b$ at surface is linked to the energy balance at the ice surface (see e.g. Luetscher et al., 2005; Obleitner and Spötl, 2011) via the terms of sublimation/deposition, freezing of seepage water and surface melting:

$$
\frac{\mathrm{d} E}{\mathrm{~d} t}=R+H+L+S+P \quad\left(\mathrm{~W} \mathrm{~m}^{-2}\right) .
$$

Equation (3) shows, that changes of internal energy $E$ of a surface layer originate from the radiation balance $R$, the sensible heat flux $H$, the latent heat flux $L$, the heat flux in the ice body $S$ and the heat transfer due to seepage water $P$. As the cave is shielded from shortwave radiation the radiation balance $R$ is reduced to the components of longwave radiation at the surface only, which are the upward component from the ice surface and the downward component from the surrounding cave walls, respectively. Though temperature gradients and related radiative fluxes between the ice and rock surfaces are small, measurements of $R$ from Obleitner and Spötl (2011) indicate that longwave net radiation constitutes the most significant energy source for the ice surface ranging between $\approx 0 \mathrm{~W} \mathrm{~m}^{-2}$ (March) and $2 \mathrm{~W} \mathrm{~m}^{-2}$ (August).

Based on a gradient approach the sensible heat flux $H$ of Eq. (3) can be estimated from the vertical temperature gradient, the density of air $\rho_{\mathrm{a}}$, the specific heat capacity of air at constant pressure $c_{\mathrm{p}}$ and a turbulence parameter $K_{\mathrm{H}}$ (which is dependent in a complex relationship on the wind speed, the ice surface roughness and the atmospheric stability see Foken, 2003):

$$
H=-\rho_{\mathrm{a}} c_{\mathrm{p}} K_{\mathrm{H}} \frac{\partial T}{\partial z} \quad\left(\mathrm{~W} \mathrm{~m}^{-2}\right)
$$

Similarly, the latent heat flux $L$ is:

$$
L=-\rho_{\mathrm{a}} L_{\mathrm{v}} K_{\mathrm{E}} \frac{\partial q}{\partial z} \quad\left(\mathrm{~W} \mathrm{~m}^{-2}\right) .
$$

Equation (5) shows that $L$ can be derived from the vertical vapour pressure gradient, the density of air $\rho_{\mathrm{a}}$, the heat of evaporation $L_{\mathrm{v}}$ and a turbulence parameter $K_{\mathrm{E}}$ (which is dependent in a complex relationship on the wind speed, the ice surface roughness and the atmospheric stability, see Foken, 2003):

If both temporal changes of surface roughness and atmospheric stability are neglected, Eqs. (4) and (5) show that, because of $c_{\mathrm{p}}$ and $L_{\mathrm{v}}$ are constants, $H$ is characterized by the surface near wind speed and the temperature gradient towards the ice surface and $L$ is dependent on the wind speed and the vapour pressure gradient towards the ice surface. Such simplification is supported from the findings of Obleitner and Spötl (2011), which showed that $H$ and $L$ are significant energy fluxes in winter and spring when both wind speeds in the cave and temperature gradients are largest, whereas both energy fluxes are close to 0 in summer and autumn when wind speeds are in the order of $0.1 \mathrm{~m} \mathrm{~s}^{-1}$ and surface near gradients of air temperature and vapour pressure are smallest. In the following we will use this approximation for qualitative estimation of turbulent energy terms (based on observations of temperature gradients and wind speed) for interpretation of ice thickness changes.

As ice-temperatures were only measured at the ice surface for the location of the meteo-stations, the heat flux in the ice body $S$ could not be quantified in this study. In summer and autumn when the ice body is isotherm $S$ is negligible, but the flux is positive in winter and spring when the ice body surface layers are cooled by the episodically invading cold air masses from outside the cave. Quantitative estimates of $S$ by Obleitner and Spötl (2011) showed that $S$ increases between January and April when $S$ reaches the magnitude of the radiative flux.

In order to assess the linkage of weather patterns inside and outside the cave to ice mass balance, spatiotemporal patterns of atmospheric conditions triggering the air flow inside the cave have to be considered. Dynamic ice caves are characterized by a clear hydrostatic behavior of air ventilation (e.g. Luetscher and Jeannin, 2004) suggesting to explain cave air flow from a simple hydrostatic model approach describing the hydrostatic imbalance in coupled columns (inside and outside the cave). Such simple model approach was developed for Eisriesenwelt by Thaler (2008). Based on the hydrostatic equation and the ideal gas law the pressure distribution in vertical air columns inside and outside the cave can be formulated as

$$
\frac{\partial p}{p}=-\frac{g}{R_{\mathrm{a}}} \frac{\partial z}{T_{\mathrm{a}}(z)} \quad(\mathrm{hPa})
$$

with $p$ is the air pressure, $T_{\mathrm{a}}(z)$ is the air temperature at vertical level $z, z$ is the vertical coordinate $g$ is the Earth gravity 


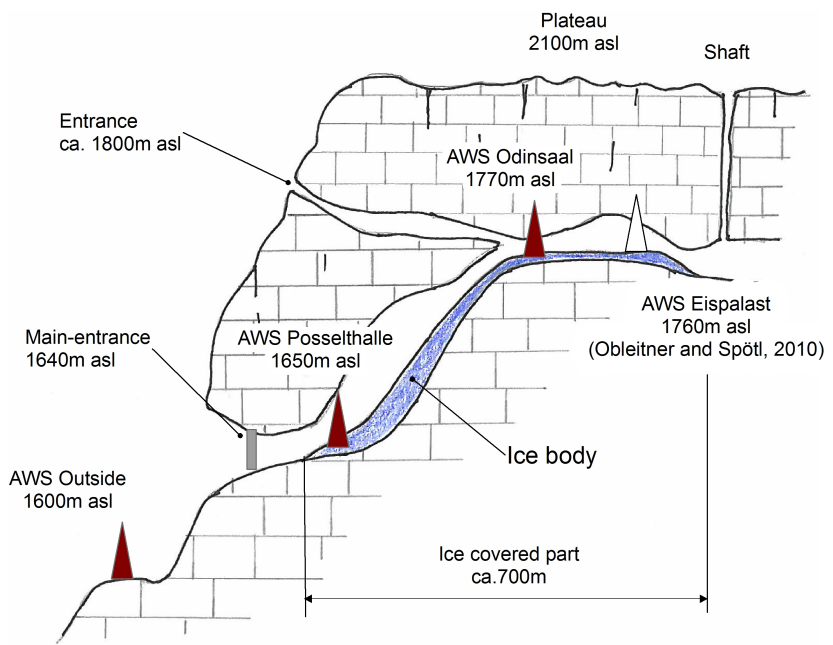

Fig. 2. Schematic of cross section of ice covered part of Eisriesenwelt cave with location of the 3 AWSs (Outside, Posselthalle unten and Odinsaal).

and $R_{\mathrm{a}}$ is the universal gas constant for dry air. The equation shows that columns mean air temperatures (and thus air density) inside and outside the cave are the essential quantities triggering air pressure gradients at level $z$ and related air flow. Additionally, the air pressure inside the cave is dependent on the air column geometry (cave geometry) and the vertical column extension in particular. As the real cave geometry capturing all entrances is not known for Eisriesenwelt, we used a generalized cave geometry derived from cave mapping (see Fig. 2) with the main entrance at $1640 \mathrm{~m}$ a.s.1. and the vertical shaft entrance at the plateau of Tennengebirge at ca. $2100 \mathrm{~m}$ a.s.1.

In fact air temperature from Eq. (6) has to be replaced by the virtual air temperature considering that the air contains a certain amount of water vapour which alters specific weight. As we could not measure vertical temperature and humidity profiles inside and outside the cave, we neither could apply the above model for computation of horizontal pressure gradients nor could we improve it considering virtual air temperature. However, we use Eq. (6) to interpret that from an initial state without air ventilation inside the cave, a temperature drop outside the cave below the inside air temperature (e.g. at the level of cave entrance) will generate an inward air flow into the cave. Similarly, a temperature rise outside the cave above the inside air temperature at the cave entrance level will result in an outward air flow.

Thus, particularly in the winter season during weather patterns with advection of cold air outside the cave entrances and as long as the air outside is cold enough to generate pressure gradients towards the inside column, the air flows into the cave. In case of an inward or outward air flow the cave atmosphere interacts with the atmosphere outside with a certain delay. From related value and direction of the energy flux at the ice surface inside the cave melting, evaporating or cooling/warming of the surface will occur.

The model based on Eq. (6) explains air circulation only from hydrostatic pressure gradients between coupled columns, but neglects any dynamical forcing of the air ventilation inside the cave. Though we cannot totally exclude dynamical forcing of air circulation in the cave, the measurements of air temperature and wind speed inside and outside the cave (Fig. 8) clearly indicates a predominant hydrostatical behavior of the cave circulation (see Sect. 4.2 for details). From there dynamical effects (which are hard to quantify, too) are omitted in this study.

\section{Measurements}

The measurement concept for this study was highly motivated from the simplified theoretical background outlined in Sect. 2. It implies to capture both the air flow inside the cave and to a certain degree the energy- and mass budget at the ice surface. Consequently, the measurements in the ERW cave covered ice surface changes as well as several meteorological variables (see Table 1 and Fig. 1 for details) at two sites inside (Odinsaal and Posselthalle) as well as, for meteorological variables only, one site outside the cave (close to the cave entrance) for the period 2007 to 2009. A generalized cross section of the ice cave and the vertical structure of observations are described by Fig. 2. Figure 3 show photographs of the two AWS installed inside ERW. Additionally, the site Eispalast is marked in Figs. 1 and 2 where high resolution mass- and energy balance measurements were performed (see Obleitner and Spötl, 2011) as part of AUSTRO*ICE*CAVE*2100. Eispalast is a larger hall in the remotest part of Eisriesenwelt ice cave and thus temporal fluctuations of ice mass and atmospheric variables are significantly smaller compared to the two AWS-sites used in this study. Such environmental conditions desired both higher resolution and higher quality sensors at site Eispalast, as described by Obleitner and Spötl (2011). Combined investigation of the data set of our study together with Eispalast-data of Obleitner and Spötl (2011) will be subject to another investigation.

As many other Alpine caves Eisriesenwelt is characterized by a complex cave passages system (in total $\approx 42 \mathrm{~km}$ including the non-ice covered part of the cave) and a highly structured ice body. Studies on air ventilation and ice thickness changes in such caves can run rather quickly into high demands on instrumentation. In order to adjust the needed instrumentation to the financial background of the project and restrictions from show cave management (several places has to be excluded), the following measurement approach was applied to this study:

- Measurement of the meteorological conditions outside the cave by one AWS close to the main entrance of the cave (measuring air temperature, vapour pressure, 
Table 1. List of meta-information on meteorological sensors used in the study.

\begin{tabular}{|c|c|c|c|c|c|c|c|c|}
\hline Site & $\begin{array}{l}\text { Air } \\
\text { temperature }\end{array}$ & $\begin{array}{l}\text { Ice surface } \\
\text { temperature }\end{array}$ & Wind direction & Wind speed & Rel. Humidity & Precipitation & Air pressure & $\begin{array}{l}\text { Ice surface } \\
\text { change }\end{array}$ \\
\hline $\begin{array}{l}\text { AWS Outside } \\
\text { Temp. Resolution } \\
\text { Accuracy }\end{array}$ & $\begin{array}{l}\text { Kroneis } 430 \\
\mathrm{HC} \\
10 \mathrm{~min} \\
0.15^{\circ} \mathrm{C}\end{array}$ & & $\begin{array}{l}\text { Kroneis } 263 \\
\text { PR } \\
10 \mathrm{~min}\end{array}$ & $\begin{array}{l}\text { Kroneis } 263 \\
\text { PR } \\
10 \mathrm{~min} \\
0.3 \mathrm{~ms}^{-1}\end{array}$ & $\begin{array}{l}\text { Kroneis } 430 \\
\mathrm{HC} \\
10 \mathrm{~min} \\
1.5 \%\end{array}$ & $\begin{array}{l}\text { Kroneis AP22 } \\
10 \mathrm{~min} \\
0.1 \mathrm{~mm}\end{array}$ & $\begin{array}{l}\text { Kroneis } 315 \\
10 \mathrm{~min} \\
0.5 \mathrm{hPa}\end{array}$ & \\
\hline $\begin{array}{l}\text { AWS Posselthalle } \\
\text { Temp. Resolution } \\
\text { Accuracy }\end{array}$ & $\begin{array}{l}\text { HOBO } \\
\mathrm{U} 12-013 \\
15 \mathrm{~min} \\
0.3^{\circ} \mathrm{C}\end{array}$ & $\begin{array}{l}\mathrm{HOBO} \\
\mathrm{U} 12-\mathrm{TMC} 6-\mathrm{HE} \\
15 \mathrm{~min} \\
0.25^{\circ} \mathrm{C}\end{array}$ & $\begin{array}{l}\text { Gill/ } \\
\text { MeteoScience } \\
\text { Propeller } \\
\text { Anemometer } \\
15 \text { min }\end{array}$ & $\begin{array}{l}\text { Gill/ } \\
\text { MeteoScience } \\
\text { Propeller } \\
\text { Anemometer } \\
15 \mathrm{~min}^{-1} \\
0.1 \mathrm{~m} \mathrm{~s}^{-1}\end{array}$ & $\begin{array}{l}\text { HOBO } \\
\mathrm{U} 12-013 \\
15 \mathrm{~min} \\
2.5 \%\end{array}$ & & & $\begin{array}{l}\text { Judd } \\
1 \mathrm{~d} \\
1 \mathrm{~cm}\end{array}$ \\
\hline $\begin{array}{l}\text { AWS Odinsaal } \\
\text { Temp. Resolution } \\
\text { Accuracy }\end{array}$ & $\begin{array}{l}\text { HOBO } \\
\mathrm{U} 12-013 \\
15 \mathrm{~min} \\
0.3^{\circ} \mathrm{C}\end{array}$ & $\begin{array}{l}\mathrm{HOBO} \\
\mathrm{U} 12-\mathrm{TMC} 6-\mathrm{HE} \\
15 \mathrm{~min} \\
0.25^{\circ} \mathrm{C}\end{array}$ & $\begin{array}{l}\text { Gill/ } \\
\text { MeteoScience } \\
\text { Propeller } \\
\text { Anemometer } \\
15 \mathrm{~min}\end{array}$ & $\begin{array}{l}\text { Gill/ } \\
\text { MeteoScience } \\
\text { Propeller } \\
\text { Anemometer } \\
15 \mathrm{~min} \\
0.1 \mathrm{~m} \mathrm{~s}^{-1}\end{array}$ & $\begin{array}{l}\text { HOBO } \\
\mathrm{U} 12-013 \\
15 \mathrm{~min} \\
2.5 \%\end{array}$ & & & $\begin{array}{l}\text { Judd } \\
1 \mathrm{~d} \\
1 \mathrm{~cm}\end{array}$ \\
\hline
\end{tabular}
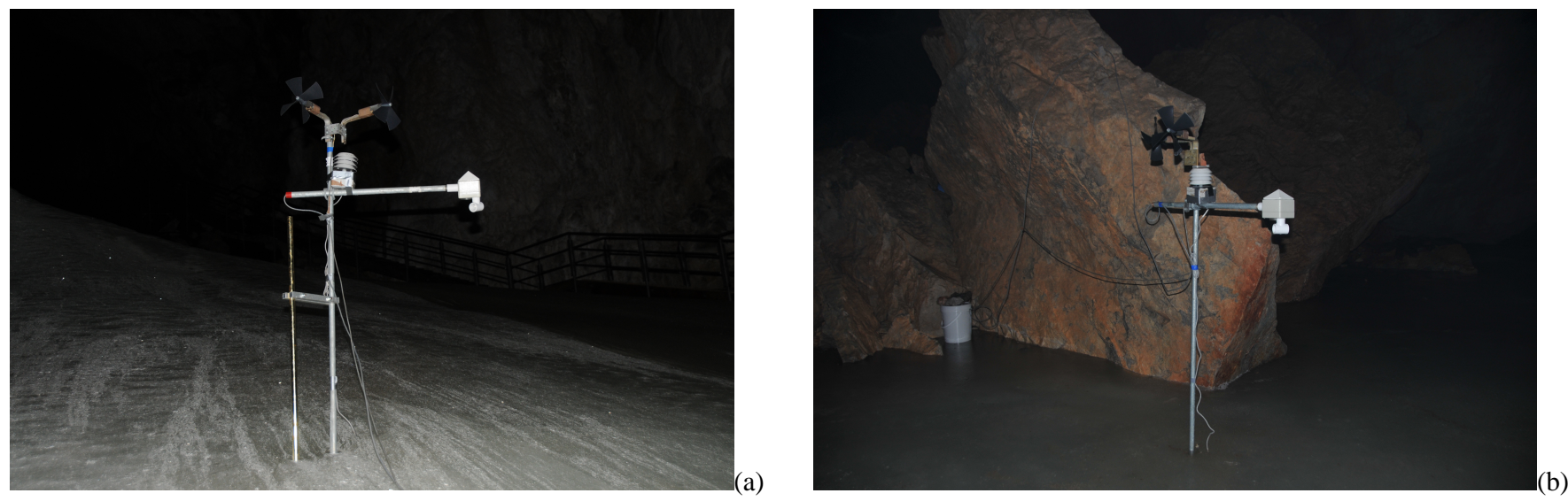

Fig. 3. The automatic weather station AWS close to the cave entrance at site Posselthalle (a) and in the central part of Eisriesenwelt at site Odinsaal (b) (see Fig. 1 for location of the AWS).

air pressure, wind speed, wind direction and precipitation). Though other, much smaller, entrances of the cave were known from detailed cave mapping, their influence could not be quantified in this study.

- Capturing of the cave atmosphere conditions at two sites by simple AWSs (measuring air temperature, humidity, wind speed, wind direction, ice surface temperature) one close to the entrance and one in the middle part of the ice-covered area of the cave, considering both demands from show-cave management as well as the spatial representativeness of measurements.

- Estimation of changes of ice mass from both a spatially dense network of ice stakes (with non-regular manual readings) accompanied by automatic readings located at the two AWS sites, supplementing the spatially dense information of the stakes by temporally high-resolution data of ice-surface changes.

In order to qualitatively characterize the turbulent energy fluxes between the ice-surface and the surface-near caveatmosphere (sensible and latent heat flux), ice surface temperature was an essential parameter to be measured in addition to atmospheric conditions and ice elevation changes. Additionally, ice surface temperatures were useful data to characterize the ice surface with respect to melt or evaporation conditions (e.g. ice loss for negative ice temperatures could be associated to evaporation events only). Measurement of ice surface temperatures can be done by infrared thermometers which are however difficult to calibrate. We instead used surface-near temperature sensors (installed 


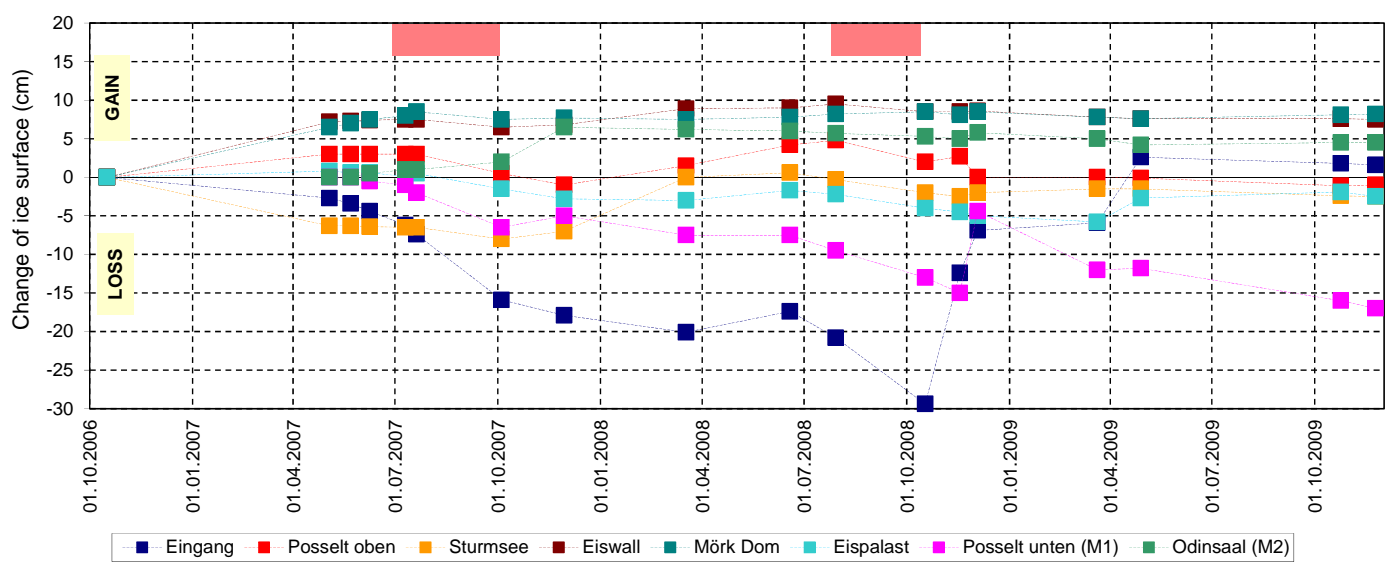

Fig. 4. Time series of accumulated ice surface changes of Eisriesenwelt ice body measured by manual stake readings within the period 1 October 2006 and 29 October 2009. The red bars mark summer/autumn periods with ice loss at almost all stakes.

$1-2 \mathrm{~cm}$ below the ice surface) which worked in a satisfactory manner because of the rather stable ice surface conditions. Exception was the entrance near site in late summer/autumn when stronger ablation happened. For this period the surface temperature could only temporarily measured but was clearly $0{ }^{\circ} \mathrm{C}$ over the entire period of surface melt.

Surface changes were measured by two different methods, manual stake reading und ultrasonic range sounding (US-sensors), respectively. For manual stake readings plastic stakes were drilled into the ice by a steam drill at eight locations (see Fig. 1 for location). The stakes were measured at each visit of the cave, with a total of 18 readings available within the period 16 October 2006 and 24 November 2009. All stake readings are summarized in Fig. 4. Ultrasonic range measurements were performed at two sites (see Fig. 1: Meteo "Posselthalle" and Meteo "Odinsaal") offering permanent measurements of ice surface changes. US-Sensor data were stored with Campbell CR200 data loggers. Both US-Sensors and Campbell loggers worked well without any data loss within the entire period starting October 2007 and ending September 2009. Whereas the weather station at site Odinsaal was situated at a plane part of the cave, weather station Posselthalle was very near to the cave entrance with surface inclination of the ice body of about $20^{\circ}$. Additionally, the two measurement sites are different in cave geometry. In particular, site Odinsaal is a narrow part of Eisriesenwelt (close to the bottleneck site "Sturmsee") with significant higher wind speeds (see Fig. 7) compared to site Posselthalle. Considering cross sectional area, Posselthalle is the largest room of the ice covered part of Eisriesenwelt.

Meteorological measurements were performed in the cave using both standard mobile automatic weather station (enterprise Kroneis, Austria, Kroneis, 2010) of the Austrian weather service (ZAMG) for the outside station as well as automatic weather station specifically adapted for measurements inside the cave (see Table 1 for details). A rather big challenge for the measuring network was permanent power supply as the cave is closed and inaccessible (because of avalanche danger) during winter season. In the winter season 2006/2007 power supply for AWSs was provided by the show cave installations, which however, broke down very early in the winter season and no data were measured. From this experience the power supply were changed to batteries since 2007 which worked well until the end of observations in 2009. The meteorological stations were maintained during each visit of the cave (see the date of stake observations which agrees with maintenance dates). Data was stored by data loggers (HOBO-U12 and Campbell CR200 for wind and ultrasonic surface height sensors) and was downloaded during each field visit. HOBO-U12 sensors were replaced several times and maintained at office. Calibration of Judd ultrasonic height sensors and Gill propeller anemometers were done before the installation in the field, whereas temperature and humidity sensors were calibrated before and after field measurements.

\section{Results}

\subsection{Spatial and temporal changes of the cave ice body height}

Results from the manual readings of the ice stakes of ERW are shown in Fig. 4. Though it is evident that the spatial variability of ice height changes is large and that clear patterns of ice built-up and ice loss are hard to derive, the general picture is that ice loss occurred in winter and summer whereas ice gain (if even observed) was measured in spring and autumn (mass gain in autumn is most likely affected from artificial water intake into the cave by cave operators). However, neither significant built-up of ice in spring from refreeze of draining snow-melt water nor spatially homogenous ice 

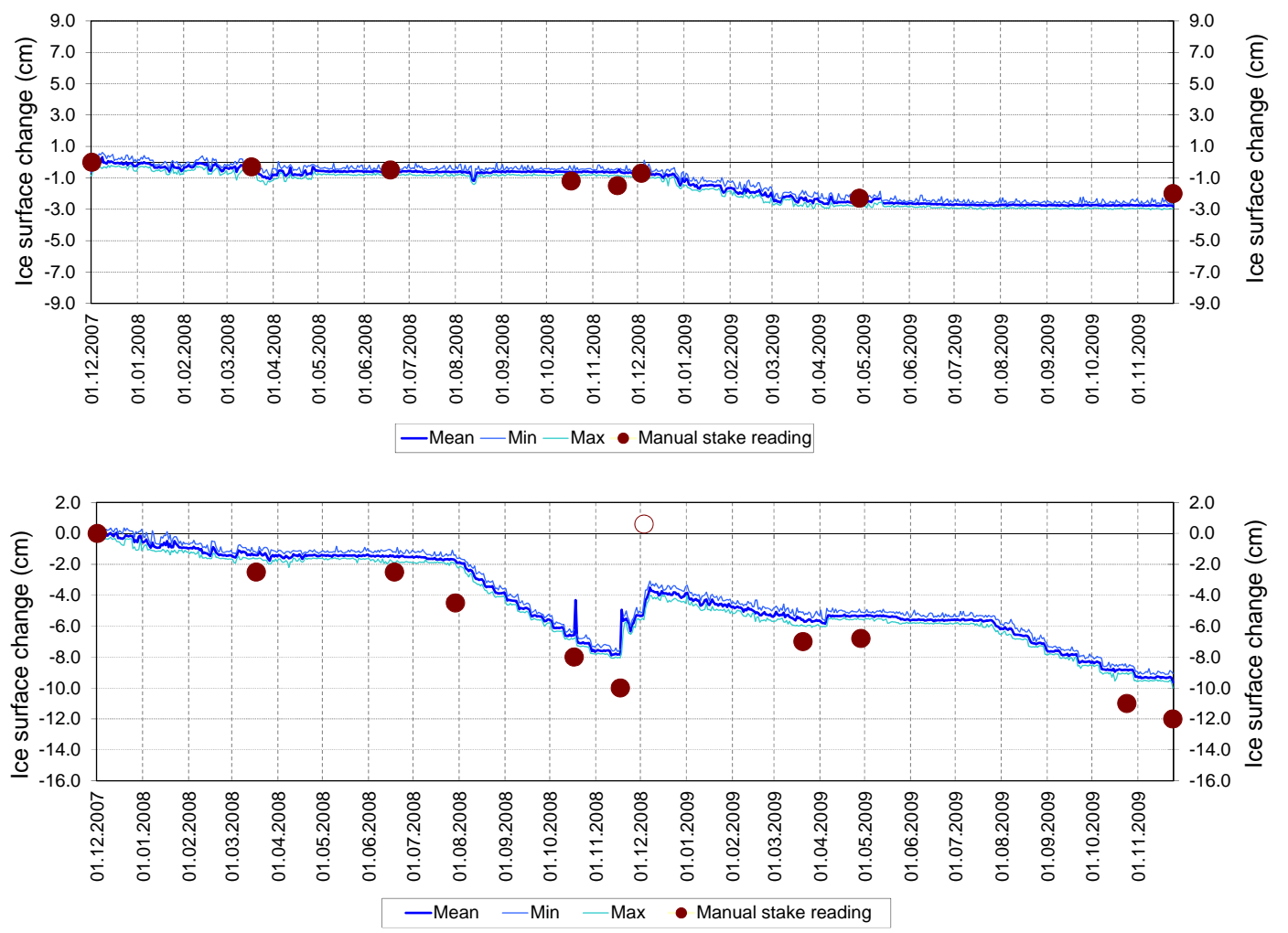

Fig. 5. Time series of accumulated ice surface changes of Eisriesenwelt ice body measured by ultrasonic range sensors at two sites Odinsaal (top panel) and Posselthalle unten (bottom panel) for the period 1 December 2007 and 29 October 2009. For ultrasonic measurements for each day the minimum value (Min), the maximum value (Max) as well as the mean value (Mean) of hourly readings are shown. The net change over the entire period of observations is $-3 \mathrm{~cm}$ for Odinsaal and $-9 \mathrm{~cm}$ for Posselthalle unten from the ultrasonic measurements. The white dot marks an implausible manual reading.

loss from melt in summer were identified. Most distinct ice mass changes were measured for cave-entrance near stakes with clear ice loss in summer and strong ice gain (of up to about $25 \mathrm{~cm}$ ) in late autumn 2008. In general ice changes were rather small and spatially inhomogeneous. Additionally, it was observed that the temporal variability of ice surface changes decreases with distance from the cave entrance, which was in agreement with the temporal variability of meteorological variables in the cave, to be shown later. In overall the ice body seemed to be in a rather stable state over the period of observations, with the exception of stake "Posselthalle unten" which lost about $20 \mathrm{~cm}$ of ice.

More detailed information on the temporal fluctuations of ice changes can be derived from the continuous ice surface measurements using the ultrasonic range sensors (Fig. 5). Over the entire period the US-measurements are in fairly good agreement with parallel measurements from stakes with exception of one observation for site "Posselthalle unten", which maybe resulted from an error during manual observations. Though the observed changes for the two sites were rather small, in particular for the site Odinsaal, a clear temporal behaviour can be derived from the measurements. For both sites the series started with a rather weak mass loss in winter in the order of about $1-2 \mathrm{~kg} \mathrm{~m}^{-2}$ occurring between about the end of November until about April of the subsequent year. After this period of weak mass loss the ice body remained stable until approx. begin of August (for the entrance-near site) respective November (for the site in the middle of the ice-covered part of the cave). Whereas the site in the middle section of the cave experienced no ice loss in summer the entrance-near site showed a clear loss in late summer and early autumn. Surprisingly, the entrance-near site showed a significant mass gain for late autumn 2008, which contradicts the idea of ice accumulation from refreezing snow-melt water, as significant snow melt was not observed during this period. Most likely this feature has to be explained from artificial cave runoff management. The same annual pattern with slightly different values as for 2008 was observed for 2009.

In essence the annual cycle of ice surface elevation changes can be generalized from the two-year observations as:

- weak mass loss in winter 
- stable conditions in spring for the entrance-near site of the cave and from spring until autumn for the inner site of the cave

- mass loss for late summer and autumn for the entrancenear site of the cave

In order to get a clearer signal of ice height changes longer time series would be useful, which are not available for Eisriesenwelt. There are, however, series of photographs of the cave ice conditions back the begin of the 20th century in particular for the site Eispalast. Comparison of these old photographs with recent one clearly indicates a mass loss of about $10-20 \mathrm{~cm}$ since the 1920s for the site Eispalast (Spötl et al., 2008), where comparisons benefits from the flat structure of the ice surface. This value is certainly not representative for present values of ice changes at the site Eispalast (Obleitner and Spötl, 2011).

\subsection{Linkage between atmospheric conditions inside and outside the cave}

Figure 6 gives a rough overview on atmospheric conditions inside and outside the cave Eisriesenwelt from monthly means of air temperature and wind speed. The figure clearly shows that average atmospheric winter conditions were colder in 2008/2009 compared to 2007/2008 for both inside and outside the cave and that the average wind speed during winter was higher in 2008/2009 compared to 2007/2008, too. This finding supports the theory from Eq. (6) as stronger temperature gradients from inside to outside the cave (in winter) induce larger pressure gradients between outside and inside the cave (with opposite sign) and consequently higher wind speeds in the cave. Additionally, it can be seen from Fig. 6 that the wind speed outside the cave is not linked to the wind inside the cave. Thus significant influence of dynamical forcing on air ventilation in the cave is rather unlikely.

A more detailed picture of the interaction between the atmosphere inside and outside the cave in the winter period can be seen from Fig. 7 for the period 1 December 2007 to 31 May 2008. Whenever the air temperature outside the cave dropped below the air temperature inside the cave the air moved into the cave (triggered from the air pressure gradient described by Eq. 6). The air flow into the cave is not only reflected by the clear temperature drop inside the cave, which delays from the entrance towards the inner parts of the ice cave by $1 \mathrm{~h}$ or even more, but also from the significant increase of the wind speed inside the cave during such events. As soon as the temperature level outside the cave returned to warmer temperatures than inside the pressure gradient levelled out and the inward air flow stopped or even reversed. It can be clearly seen from Fig. 7 that the typical winter inward air flow was not stable throughout the winter season but was interrupted in many cases by advection of warmer air masses outside the cave. In the middle of April the predominate inward air flow significantly decreased and levelled
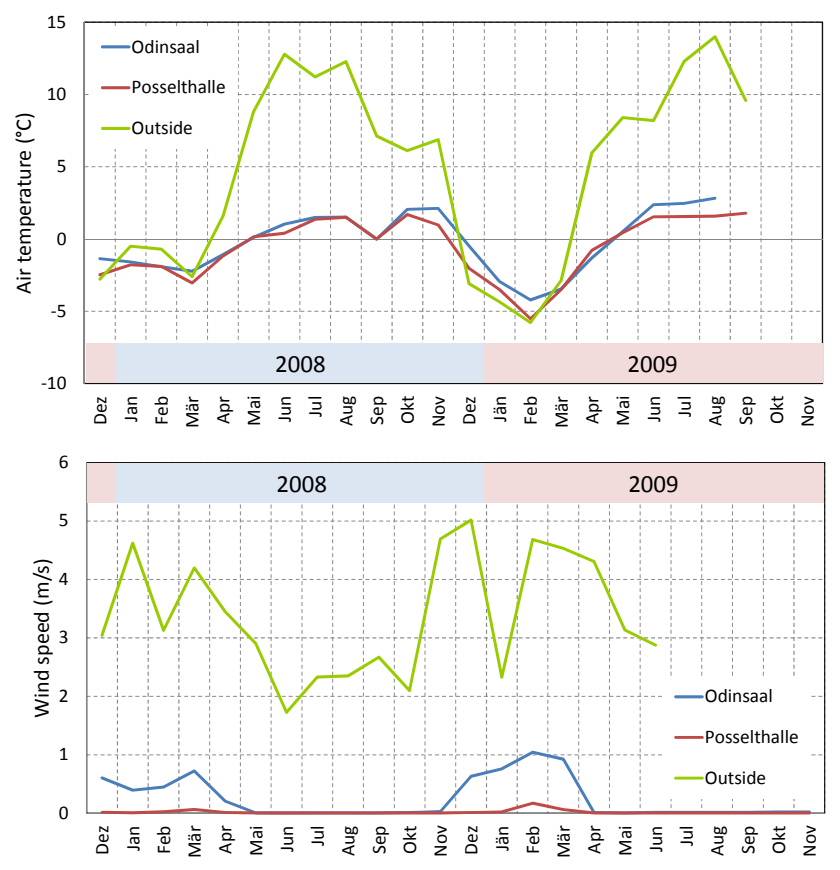

Fig. 6. Monthly averages of air temperature (top panel) and wind speed (bottom panel) at two AWS sites in cave Eisriesenwelt and one site outside the cave close to the entrance for the period December 2007 to October 2009.

out at the begin of May 2008. The same general picture as for winter-spring-autumn 2007-2008 was observed for the year 2008-2009 (not shown here).

During summer the cave air temperature was rather stable at the level of $1-2{ }^{\circ} \mathrm{C}$ at the two sites Odinsaal and Posselthalle (see Fig. 7). A striking feature of summer temperature behaviour, however, can be seen from Fig. 8. Both measurement sites show a clear diurnal cycle of the air temperature which is quite independent from the air temperature outside the cave. In particular, every day the air temperature quickly increased after 7 o'clock by about 0.5 to $0.8^{\circ} \mathrm{C}$ approaching the maximum at about 1 o'clock p.m. Thereafter the air temperature decreased to the next minimum phase during the night. The daily cycle was well established and stable during summer and autumn. Possibly the cycling has something to do with the management of the cave which starts with the first activities and first opening of the entrance in the morning and ends up with the closure of the cave-entrance in the evening (the door has been only opened to leave visitors in and out). In particular the intermittent opening of the door during daytime in summer initiated an outflow of the cold- dense air from the cave (with rather high wind speeds observed during visits) and increased the temperature by replacing warmer air masses from the inner-parts of the cave. During night, however, the outflow of cold air is blocked from the door generating again a cold air pool in the lowest part of the cave in the area of the entrance. Figure 8 also shows that air temperature at site Odinsaal 


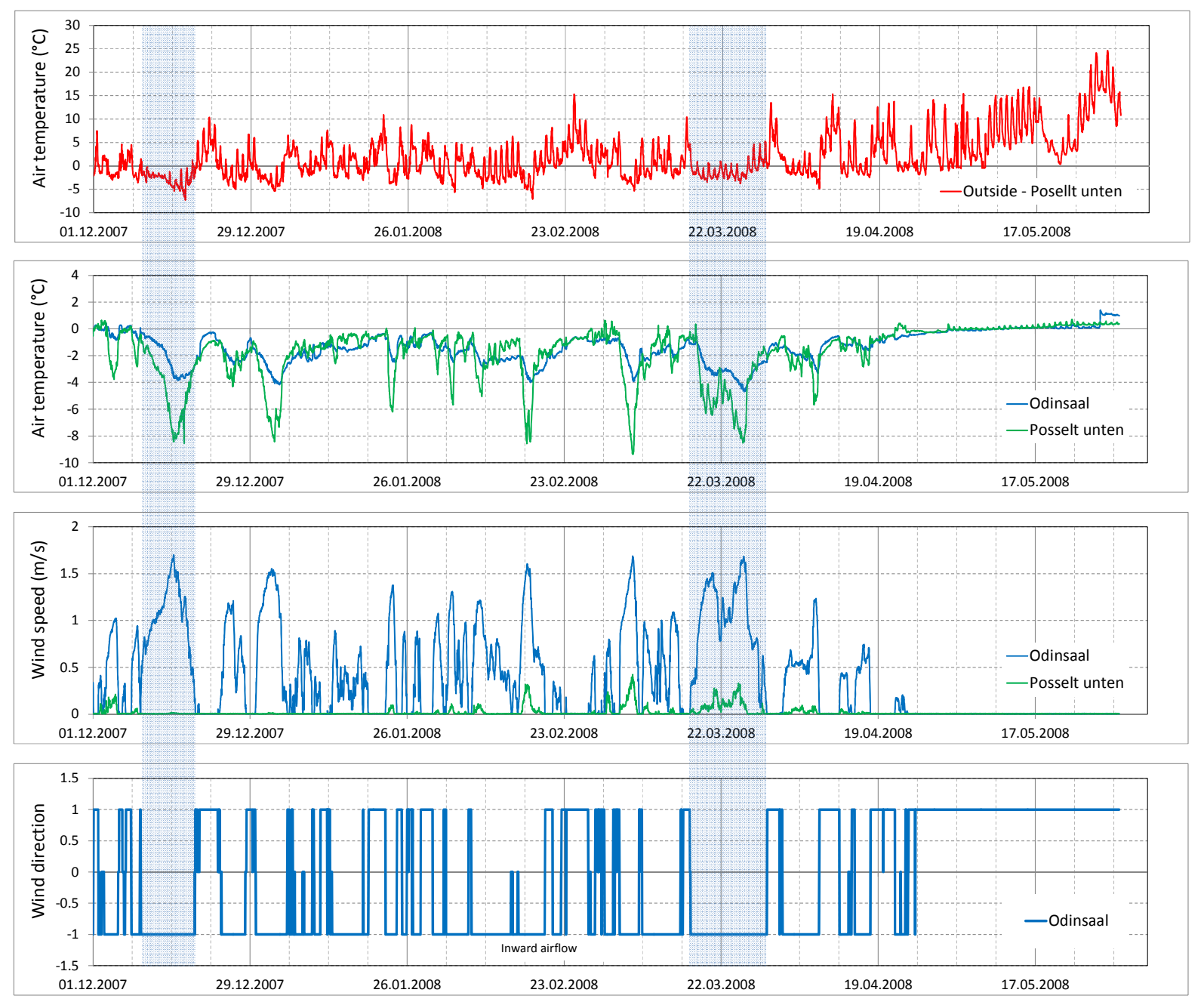

Fig. 7. Daily cycle of air temperature (hourly values) for the two AWS-locations Posselthalle and Odinsaal as well as the weather-station outside the cave Eisriesenwelt for the period 26 July 2008 to 15 August 2008.

exceeded air temperature at site Posselthalle in August 2008, which indicates that site Odinsaal most probably was influenced from invading air masses from the second horizontal entrance shown in Fig. 2.

\subsection{Cave atmospheric conditions and ice mass changes}

In the next step the atmospheric measurements inside and outside the cave from the AWSs are used to asses general features of the energy balance at the ice surface and to compare them to measured ice changes. It was shown in Sect. 2 by Eqs. (4) and (5) that the temperature gradient and the vapour pressure gradient towards the ice surface as well as the wind speed are essential parameters of the turbulent energy fluxes. Whereas the surface near temperature gradients were measured at both AWS sites, observations of vapour pressure gradients were neither measured nor could be derived from relative humidity measurements at the AWS sites as this data was not reliable (too harsh measuring conditions for the sensors at relative humidities close to $100 \%$ ). However, assuming total saturation ( $100 \%$ relative humidity, which is realistic approximation for Alpine caves) vapour pressures both over the ice surface as well as for the atmosphere $(\approx 1 \mathrm{~m}$ over ground) could be computed from temperature measurements (of ice and air respectively) using empirical approximations (e.g. the Magnus formula), which estimates water vapour pressure $E_{\mathrm{a}}$ (for air) as:

$$
E_{\mathrm{a}(t)}=E_{0} \exp \left(\frac{17.62 t}{243.14+t}\right) \quad(\mathrm{hPa})
$$

and $E_{\mathrm{i}}$ (for vapor pressure over ice) as:

$$
E_{\mathrm{i}(t)}=E_{0} \exp \left(\frac{22.46 t}{272.62+t}\right) \quad(\mathrm{hPa})
$$

and for $E_{0}=6.112 \mathrm{hPa}\left(\mathrm{t}\right.$ is the air temperature in $\left.{ }^{\circ} \mathrm{C}\right)$. 


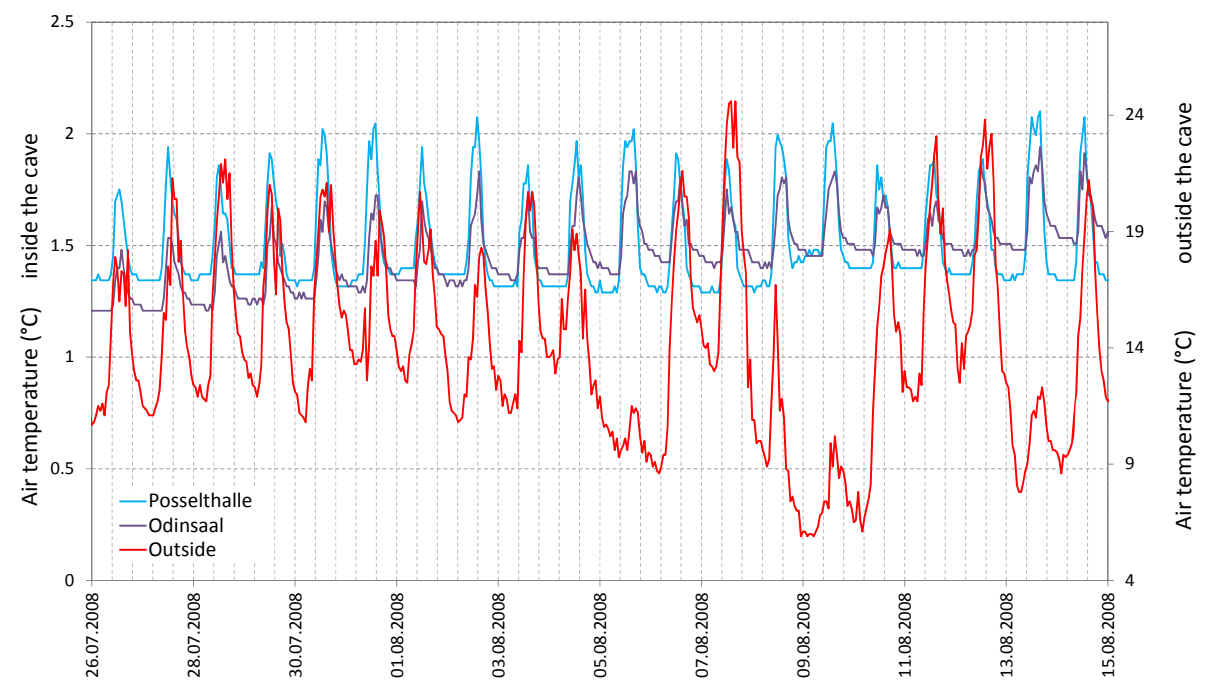

Fig. 8. Hourly values of air temperature difference (outside at the level of cave main entrance minus site Posselthalle unten), air temperature (green line $=$ AWS close to the entrance, blue line $=$ AWS in the middle part of the cave), wind speed and wind direction (bottom panel, AWS in the middle part of the cave only) in the cave Eisriesenwelt for the period 1 Decmeber 2007 to 31 May 2008. Wind direction values of +1 mean outward flow, values -1 means inward flow. The shaded areas mark two examples of periods with inward air flow triggered from density gradients when the outside air is colder than inside the cave.

Using Eqs. (7) and (8) vapour pressures were computed from air temperatures and ice temperatures for AWS sites Odinsaal and Posselthalle, respectively (see Fig. 10 for the period October 2008 to June 2009). Analysis of computed data of vapour pressure shows that during the winter/spring period between December and April the vapour pressure over the ice body was generally larger than the vapour pressure of the cave atmosphere at the level of temperature sensors, clearly indicating ice evaporation. As the wind speed was significantly increased during those periods with vapour pressure gradients from the ice surface towards the cave atmosphere (Fig. 7), eddy diffusivity was increased, too, thus enforcing the latent heat flux from the ice body to the cave atmosphere. Though, this is only rough information on the latent heat flux, as computation of latent heat flux would need more precise meteorological measurements as well as information on eddy diffusivity, it is a clear indication on the sign and the value of latent heat flux at the ice surface.

In Sect. 4.1 a typical annual cycle of ice surface changes was shown with clear ice loss in winter/spring and summer (the latter for the entrance-near parts only) as well as, for the entrance-near site, distinct ice accumulation in late autumn 2008. As described above, ice loss in winter can be well explained from ice evaporation which is suggested from the negative ice surface temperatures and the vapour pressure gradients (see Fig. 10) for both sites. Simple estimation of the required latent heat flux in order to explain ice surface height changes (using latent heat of evaporation of ice $=2.834 \times 10^{6} \mathrm{~J} \mathrm{~kg}^{-1}$ ) for the period 1 December 2007-1 April 2008 gives $\approx 3.0 \mathrm{~W} \mathrm{~m}^{-2}$ for site Posselthalle and $1.0 \mathrm{~W} \mathrm{~m}^{-2}$ for site Odinsaal as well as
$4.0 \mathrm{~W} \mathrm{~m}^{-2}$ (Posselthalle) and $3.6 \mathrm{~W} \mathrm{~m}^{-2}$ (Odinsaal) for the period 1 December 2008-1 April 2009. These values are higher compared to the modelling results of Obleitner and Spötl (2011) for the site Eispalast. However, either vapour pressure gradients (site Posselthalle) or wind speeds (site Odinsaal) were significantly higher compared to the site Eispalast and therefore computed values of latent heat fluxes for Odinsaal and Posselthalle are plausible.

Importance of sublimation for ice ablation in Eisriesenwelt is further supported by the existence of well-established cryogenic carbon layers in the ice wall at the site Mörkdom. These layers, as described by Spötl (2008), were built by freezing of calcium-rich cave waters, thereafter enriched by sublimation (and maybe melt) forming white-brown horizontal layers in the ice body. The large number of cryogenic carbon layers covering the entire ice wall at Mörkdom underlines the contribution of sublimation to mass balance of Eisriesenwelt ice body on a long time scale. A high contribution of sublimation to ice loss in an ice cave was also shown by Rachlewicz and Szczucinski (2004) from extensive measurements in Janskinia Lodowa w Ciemniaku (Tatra Mountains, Poland). However, additional to the strong ice loss due to sublimation in winter ( $30 \%$ of the total loss) this cave also experiences high loss from ice melt in summer and autumn (70\% of the total loss).

Whereas ice loss in winter can be well explained from sublimation, ice ablation in summer can be only associated to surface melt, as during these periods vapour pressure gradients did not allow sublimation. In fact, the ice ablation in summer (observed by ultrasonic sensors) started as soon as the ice surface temperatures approached the threshold of $0{ }^{\circ} \mathrm{C}$ 


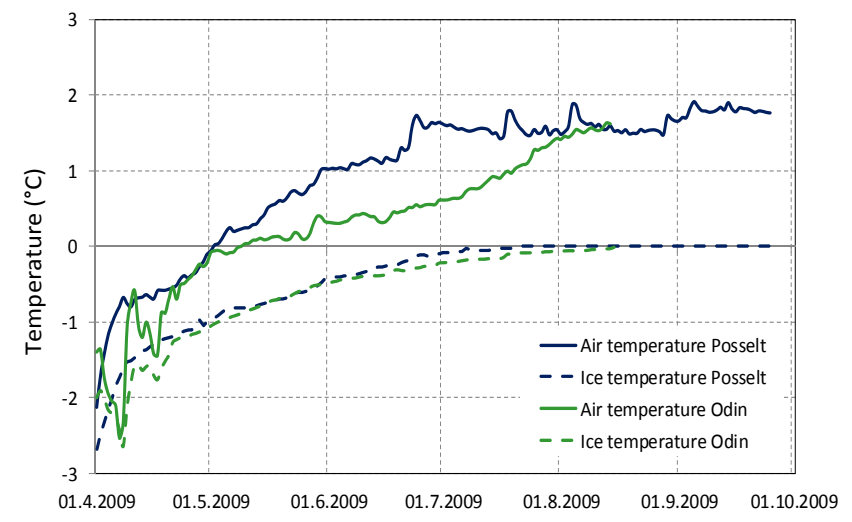

Fig. 9. Daily means of air temperature and ice temperature at two sites (Odinsaal and Posselthalle) in the cave Eisriesenwelt for the period 1 April 2009 to 30 September 2009.

(see Fig. 9) for site Posselthalle (whereas it took significant longer for site Odinsaal). At that time air temperatures at site Posselthalle were high enough, too, in order to generate melt from sensible heat flux (Eq. 4). However, eddy diffusivity was certainly weak for that period because of low wind speeds. This finding is supported from the modelling results of Obleitner and Spötl (2011) which showed that turbulent fluxes can be neglected for summer. Alternatively and more plausible, the input of energy for ablation in summer could be expected from increased longwave radiation flux from the rock surface towards the ice surface when the upward component from the ice is limited by the $0^{\circ} \mathrm{C}$ threshold of ice surface temperature. From a rough estimation of the energy flux needed for melting of the ice in summer/autumn 2008 ( $1 \mathrm{Au}$ gust to 15 November 2008) at the site Posselthalle (based on the specific heat of fusion for ice $=333.5 \times 10^{6} \mathrm{~J} \mathrm{~kg}^{-1}$ ) yields a value of $2.4 \mathrm{~W} \mathrm{~m}^{-2}$, as well as $1.4 \mathrm{~W} \mathrm{~m}^{-2}$ for summer/autumn 2009 (1 August to 24 November 2009), which are similar to modelled values reported by Spötl and Obleitner (2011) for the site Eispalast (1.5 to $2 \mathrm{~W} \mathrm{~m}^{-2}$ for summer 2008).

During the period of increasing air temperatures in May 2009 the level of $0^{\circ} \mathrm{C}$ was exceeded rather quickly. This is shown by Fig. 9 for the period 1 April to 1 October 2009 for both AWS sites, Odinsaal and Posselthalle, and was observed very similar for the spring 2008 , too (not shown here). It is however a clear feature of Fig. 9 that, compared to air temperature, ice temperature needed much longer to reach $0{ }^{\circ} \mathrm{C}$, indicating that the ice did not melt before approx. the begin of August in 2009 (again this finding is in good agreement for summer 2008, not shown), with a delay towards the more inner site (Odinsaal) of the cave.

Surprisingly, both Figs. 4 and 5 show a period of distinct ice accumulation in late autumn 2008. This accumulation period, however, cannot be simply associated to measured meteorological conditions inside or outside the cave. Ice accumulation would need significant refreezing of seepage
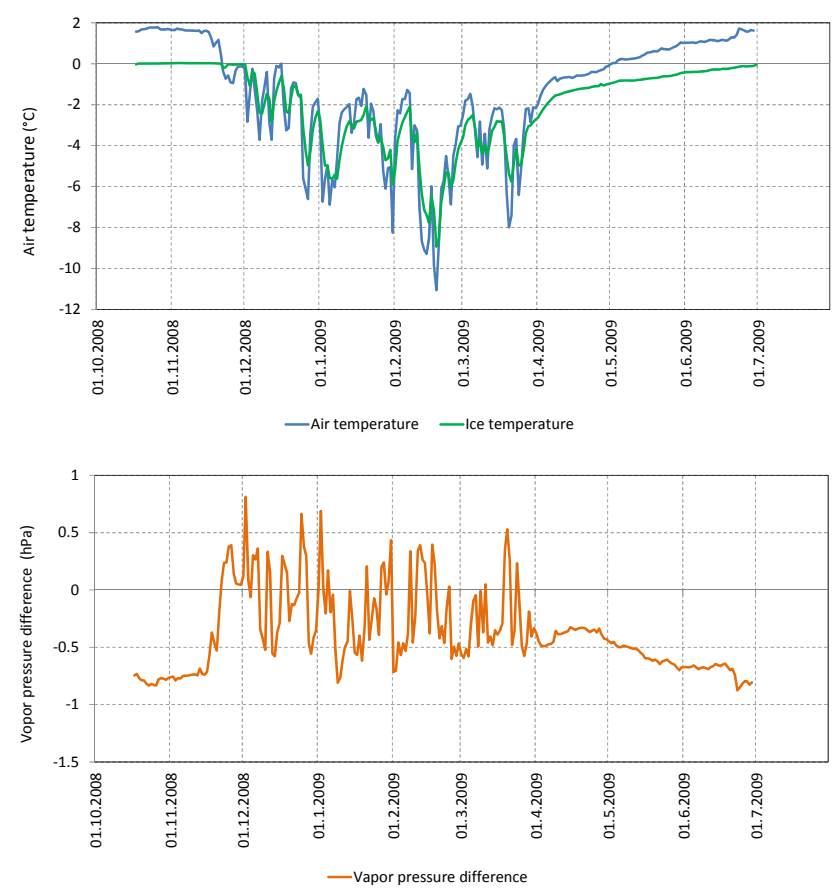

Fig. 10. Daily means of air temperature, ice temperature (top panel) and computed vapour pressure difference (ice surface minus air) for AWS-location Posselthalle in the cave Eisriesenwelt for the period 1 April 2009 to 30 September 2009. Vapour pressure was computed from air temperatures under the assumption of saturation using the empirical Magnus-formula.

water at the ice surface which originates from precipitation or snow melt. Measurements from the weather station outside the cave, however, do not support this reason. Surface height changes for site Odinsaal show (Fig. 5) that significant refreezing of seepage water was not observed there and played no role for the ice surface energy balance. For site Posselthalle, however, refreezing of either seepage water or, more plausible, drainage water from artificial water pumping (by cave operators) was measured. Refreezing of the water was observed at a time when the ice surface was still at the $0{ }^{\circ} \mathrm{C}$ level, but the cave entrance was already opened enabling the inward air flow during cold events. Probably, the latent heat of fusion from freezing of the water effected the cave atmosphere and not the ice body.

A final synopsis of Figs. 4-10 now enables to derive a clear picture of ice body changes in the Eisriesenwelt and related atmospheric conditions inside and outside the cave. In particular significant periods of ice surface changes from Figs. 4 and 5 can be well explained from atmospheric conditions shown in Figs. 7-10:

- December-March: Whenever in the winter period the atmosphere outside the cave entrance was significantly colder than inside, a pressure gradient into the cave was established and the cold air moved from outside into the 
cave. This inward air flow was quite well reflected from a significant cooling of the air in the cave and a significant increase of the wind speed inside the cave. Additionally the wind direction in the cave during such periods was clearly inward. As the approaching air was significantly colder than the ice surface a vapour pressure gradient from the ice to the air was established and the ice body lost mass from evaporation, enforced from the increased eddy diffusivity due to the higher wind speeds. As soon as the air outside the cave warmed up (e.g. from advection of warmer air masses) the inward air flow and the ice evaporation stopped.

- April-July (AWS Posselthalle), April-November (AWS Odinsaal): In spring the air temperature outside the cave increased and air pressure gradients between inside and outside the cave levelled out. Wind speeds were now much weaker compared to the winter period. The air temperature in the cave increased to about 1$2{ }^{\circ} \mathrm{C}$ and evaporation from the ice surface was no longer observed. Contrary to air temperatures ice temperatures remained below $0{ }^{\circ} \mathrm{C}$ until summer. Thus the ice surface experienced a balanced state without any accumulation or ablation. Significant accumulation from refreezing of seepage snow-melt water was not observed.

- August-November (AWS Posselthalle only): During late summer until autumn the behaviour of the ice body was characterized by significant ice loss for the entrance-near parts of the cave. The different behaviour of the entrance-near and the remote parts of the cave was well reflected in the ice and air temperature measurements, respectively, which were both significantly higher for the entrance-near parts of the cave. Simple qualitative consideration of energy fluxes suggests that the mass loss was triggered from increased rock surface temperatures and related radiative fluxes. The period of clear mass loss lasted until the end of November when the door of the cave entrance was opened and winter conditions started again.

As described earlier, ice bodies from ice caves are currently discussed as a valuable source of proxy data for paleoclimate reconstructions (Holmlund et al., 2005; Vrana et al., 2007; May et al., 2011; Kern et al., 2011). For instance for climate interpretation of ice core samples the seasonal reference of accumulation layers is of particular interest, from which measurements of $\delta^{18} \mathrm{O}$ stable isotopes could provide information on paleo-temperatures (see May et al., 2011). Additionally, sublimation and melt can alter the isotopic signal and thus provide further important basics for proxy-signal interpretation.

From our two-year measurements it can be clearly seen that the amount of accumulation and its seasonal reference was hard to detect and that uncertainty of its value was large because of both the small magnitude of the signal as well as the significant influence from show-cave activities. However, findings were significant for ablation processes. Under the actual climate ablation for the inner site of the Eisriesenwelt ice cave were sensitive to winter conditions only whereas the entrance-near parts of the cave were sensitive to both the winter and summer/autumn conditions. Colder winters increase ice loss due to increased sublimation, (the winter 2007/2008 was significantly warmer and experienced less ice loss compared to the winter 2008/2009) which is evident from the formulation of latent heat flux of Eq. (6). However, all results on climate sensitivity have to be seen in the light of significant uncertainty coming from the possible influence from cave-management activities on both ice and air-ventilation dynamics.

\section{Conclusions}

In this paper the ice dynamic of the Austrian ice cave Eisriesenwelt was quantified from analysis of extensive meteorological and glaciological measurements for the period 2007-2009. Focus was given to the linkage between weather patterns inside and outside the cave as well as resulting effects on ice surface changes. From the synthesis of our observations we conclude that:

- Eisriesenwelt clearly shows the typical behaviour of a dynamic ice cave, with, at the lower main entrance, well established episodic inward air flow during cold weather types in winter and rather weak outward air flow during warm weather types for both winter and summer. Inward (outward) airflow, triggered from hydrostatic imbalance between coupled air columns, is caused by air temperature gradients between inside to outside the cave.

- In spite of the currently increasing temperatures outside the cave (climate warming) the ice body of Eisriesenwelt appears in a quite balanced state. It is, however, hard to quantify to which part the balanced state results from activities of show-cave management influencing both ice changes (artificial input of refreezing water) and cave climate (hindered air ventilation due to the door at cave entrance).

- Continuous measurements of ice surface changes of the ice body show clear temporal patterns with ice loss in winter, stable conditions in spring until summer and clear melt in late summer and autumn for the entrancenear parts of the cave. Ice mass changes agrees well with energy fluxes at the ice surface roughly estimated from cave atmosphere measurements and the hydrothermal structure of the cave ice body, indicating weak sublimation in winter, melt-free conditions in spring until summer and melt conditions in late summer and autumn for the entrance-near parts of the cave. 
- Accumulation of ice in spring from refreezing of percolating snow-melt water (seepage water), as expected from general theory of ice cave formation, was measured only at single stakes and for certain periods for Eisriesenwelt. Largest amount of ice accumulation was observed for the entrance-near stakes in November 2008 (exceeding $20 \mathrm{~cm}$ for a stake close to the cave entrance) during a period without significant precipitation or snow-melt and, most probably, artificial water intake.

- Sensitivity of cave ice mass balance to the outside climate is complex and various with location inside the cave and with season. Cold winters generally decrease mean air temperature inside the cave and increase mean wind speed inside the cave and thus increase ice evaporation from enforced latent heat flux from the ice body surface to the atmosphere. In summer, however, the linkage between the outside air temperature and the ice mass balance is highly damped because of the longdistance pathway for air parcels through the cave forced from the outward flow summer circulation. Whereas the inner parts of the ice body show stable mass balances over the summer season, the entrance- near parts of the cave experience significant ice loss due to melt during summer/autumn, most probably from the radiative flux component.

- Sublimation plays a significant role for mass loss in Eisriesenwelt though values are rather small (few centimetres per year). This statement is supported from the occurrence of distinct cryogenic carbonate layers in the ice body, which are originally formed by progressive freezing of mineralized cave waters but later are concentrated by sublimation (Spötl, 2008). Interestingly, ablation from surface melt is of minor influence for the inner measurement site of the cave, but was reported to be a significant source of ablation for site Eispalast (most remote site of the ice cave) by Obleitner and Spötl (2011). On a long term perspective ice changes in Eisriesenwelt can be derived from comparison of photographs back to the begin of the 20th century, documenting a clear mass loss of about $10-20 \mathrm{~cm}$ since the 1920 s for the site Eispalast.

- For the air temperature inside the cave a clear daily cycle was observed during late spring until autumn. This cycling increases with time approaching a maximum value of $0.7{ }^{\circ} \mathrm{C}$ in summer and appears to be independent from the weather outside the cave. Additionally, it is not simply related to the activities of the operator running the show-cave (opening of the door and visits from groups of cave tourists). Further measurements are needed to understand this striking feature of Eisriesenwelt cave climate.
Acknowledgements. AUSTRIAN*ICE*CAVES*2100 was supported by the Austrian Academy of Sciences under the frame of the Programme "Alpenforschung". We are especially grateful to the Eisriesenwelt GmbH (Fritz Oedl, his team and Alois Rettenbacher in particular) for their interest in the scientific activities, for the logistic support and for the assistance during field campaigns. Georg Mursch, Bernhard Hynek, Christine Kroisleitner, Friedl Obleitner and Christoph Spötl significantly contributed during the field work.

Edited by: M. Luetscher

\section{References}

Behm, M. and Hausmann, H.: Eisdickenmessungen in alpinen Höhlen mit Georadar, Die Höhle, 58, 3-11, 2007.

Foken, T.: Angewandte Meteorologie, ISBN 3-540-00322-3, Springer-Verlag, Berlin, Heidelberg, New York, 289 pp., 2003.

Hauser, E. and Oedl, R.: Die große Eishöhle im Tennengebirge (Salzburg, Eisriesenwelt), V. Eisbildungen und meteorologische Beobachtungen, Speläologische Monographie, Wien, 6, 77-105, 1923.

Hausmann, H. and Behm, M.: Imaging the structure of cave ice by ground-penetrating radar, The Cryosphere, 5, 329-340, doi:10.5194/tc-5-329-2011, 2011.

Homlund, P., Onac, B., Hansson, M., Holmgren, K., Mörth, M., Nymann, M., and Persiou, A.: Assessing the paleoclimate potential of cave glaciers: the example of Scarisoara Ice Cave (Romania), Geogr. Ann. A, 87(1), 193-201, 2005.

Kroneis GmbH: Produktübersicht und Preisliste, available at: http: //www.kroneis.at/preisliste.pdf (last access: 29 June 2011), 2010.

Luetscher, M.: Process in ice caves and their significance for paleoenvironmental reconstructions, PhD thesis, Swiss Institute for Speleology and Karst Studies (SISKA), La Chaux-de-Fonds, 151, 2005.

Luetscher, M. and Jeannin, P. Y.: A process-based classification of alpine ice caves, Theor. Appl. Karstol., 17, 5-10, 2004.

Luetscher, M., Lismonde, B., and Jeannin, P. Y.: Heat exchanges in the heterothermic zone of a karst system: Monlesi cave, Swiss Jura Mountains, J. Geophys. Res., 113, F02025, doi:10.1029/2007JF000892, 2008.

May, B., Spötl, C., Wagenbach, D., Dublyansky, Y., and Liebl, J.: First investigations of an ice core from Eisriesenwelt cave (Austria), The Cryosphere, 5, 81-93, doi:10.5194/tc-5-81-2011, 2011.

Obleitner, F. and Spötl, C.: The mass and energy balance of ice within the Eisriesenwelt cave, Austria, The Cryosphere, 5, 245257, doi:10.5194/tc-5-245-2011, 2011.

Oedl, R.: Die Vermessung der grossen Eishöhle im Tennengebirge. Salzburg (Eisriesenwelt), Späleologisches Jahrbuch, Vol. III, 3/4, Speläologisches Institut beim BM für Land- und Forstwirtschaft, Vienna, 51-168, 1922.

Ohata, T., Furukawa, T., and Higuchi, K.: Glacioclimatological study of perennial ice in the Fuji Ice Cave, Japan, Part 1, Seasonal variation and mechanism of maintenance, Arctic Alpine Res., 26, 227-237, 1994a. 
Ohata, T., Furukawa, T., and Higuchi, K.: Glacioclimatological study of perennial ice in the Fuji Ice Cave, Japan, Part 2, Interannual variation and relation to climate, Arctic Alpine Res., 26, 238-244, 1994b.

Persoiu, A., Feier, I., Citterio, M., Turri, S., and Maggi, V.: Preliminary data on air temperature in Focul Viu Ice Cave (Bihor Mts., Romania), in: Proceedings of 2nd International Workshop on Ice Caves - Demänovska Dolina, Slovak Republic, 8-12 May 2006, 62-64, 2007.

Persoiu, I. and Onac, B.: Climate variability during the last 2,000 years: an Eastern European cave ice core perspective, Geophys. Res. Abstr., Vol. 12, EGU2010-13491, 2010.

Pfarr, T. and Stummer, G.: Die längsten und tiefsten Höhlen Österreichs, Sonderheft Nr. 35 Die Höhle, Verband Österreichischer Höhlenforscher, Wien, 1-248, 1988.

Pflitsch, A., Piasecki, J., Sawinski, T., Zelinka, J., and Strug, K.: Development and Degradation of Ice Crystals Sediment in Dobšinska Ice Cave (Slovakia), in: Proceedings of 2nd International Workshop on Ice Caves - Demänovska Dolina, Slovak Republic, 8-12 May 2006, 38-49, 2007.

Rachlewicz, G. and Szczucinski, W.: Sesonal, annual and decadal ice mass balance changes in the ice cave Jaskinia Lodowa w Ciemniaku, the Tatra Mountains, Poland, Theor. Appl. Kastrol., 17, 11-18, 2004.

Racovita, G. and Onac, B.: Scarisoara Glacier Cave - Monographic study, Editura Carpatica, 1-139, 2000.
Saar, R.: Eishöhlen, ein meteorologisch-geophysikalisches Phänomen, Untersuchungen an der Rieseneishöhle (R. E. H.) im Dachstein, Oberösterreich, Geogr. Ann. A, 38, 1-63, 1956.

Saar, R.: Zur Frage des Einflusses der Grosswetterlage auf die Dynamik der Wetterhöhlen, Die Höhle, 8, 33-44, 1957.

Silvestru, E.: Perennial ice in caves in temperate climate and its significance, Theor. Appl. Karstol., 11, 83-93, 1999.

Spötl, C.: Kryogene Karbonate im Höhleneis der Eisriesenwelt, Die Höhle, 59(1-4), 26-36, 2008.

Spötl, Ch., Wagenbach, D., Obleitner, F., May, B., Behm, M., Schöner, W., Hausmann, H., Pavuza, R., Thaler, K., and Schöner, M.: AUSTRO ICE CAVES-2010, Final project report, 51 pp., 2008.

Thaler, K.: Analyse der Temperaturverhältnisse in der Eisriesenwelt-Höhle im Tennengebirge anhand einer 12jährigen Messreihe, Diploma thesis, University of Innsbruck, Innsbruck, Germany, 2008.

Vrana, K., Baker, J., Clausen, H. B., Hansen, S. B., Zelinka, J., Rufli, H., Ockaik, L., and Jonocko, J.: Continental ice body in Dobsinska Ice Cave (Slovakia) - Part 1. - Project and sampling phase of isotopic and chemical study, in: Proceedings of 2nd International Workshop on Ice Caves - Demänovska Dolina, Slovak Republic, 8-12 May 2006, 24-28, 2007. 